\title{
Can growth hormone treatment improve growth in children with severe growth failure due to anorexia nervosa? A preliminary pilot study
}

\section{Juliane Léger 1,2,3, Anne Fjellestad-Paulsen', Anne Bargiacchi" ${ }^{4}$, Catherine Doyen', Emmanuel Ecosse ${ }^{1}$, Jean-Claude Carel ${ }^{1,2,3}$ and Marie-France Le Heuzey ${ }^{4}$}

${ }^{1}$ Assistance Publique-Hôpitaux de Paris, Hôpital Robert Debré, Service d'Endocrinologie Diabétologie Pédiatrique Centre de Référence des Maladies Endocriniennes de la Croissance et du développement, Paris, France 2Université Paris Diderot, Sorbonne Paris Cité, Paris, France

${ }^{3}$ Institut National de la Santé et de la Recherche Médicale (INSERM), Unité 1141, DHU PROTECT, Paris, France

${ }^{4}$ Assistance Publique-Hôpitaux de Paris, Hôpital Robert Debré, Service de Psychiatrie de l'Enfant et de l'Adolescent, Centre de Référence des Maladies Endocriniennes de la Croissance et du développement, Paris, France
Correspondence should be addressed to J Léger

Email

juliane.leger@rdb.aphp.fr

\begin{abstract}
Background/Aims: Growth failure is a difficult but key aspect of care in children with anorexia nervosa (AN). The effects of hGH therapy have not been studied. The aim was to investigate the effect of hGH treatment on height velocity (HV) in children with AN. Methods: We carried out a retrospective observational study. Ten girls diagnosed with AN at $10.0 \pm 1.9$ years, with prolonged severe growth failure $(H V<2.5 \mathrm{~cm} /$ year for at least 18 months) at the age of $13.3 \pm 1.1$ years and delayed puberty after nutritional rehabilitation, were treated with hGH $(0.040 \mathrm{mg} / \mathrm{kg} /$ day $)$ from a bone age of $10.9 \pm 1.7$ years until they reached adult height. Height and HV were measured before treatment and at 12-month intervals during treatment.

Results: Mean body mass index SDS remained unchanged, but HV increased significantly, from a median of $1.0(0.7-2.1)$ to $7.1(6.0-9.5) \mathrm{cm} /$ year after one year $(P<0.002)$ and $5.6(4.8-6.2) \mathrm{cm} /$ year after two years of treatment. Height SDS increased from $-2.2 \pm 1.3$ to $-1.6 \pm 1.3$ after one year $(P<0.002)$ and $-1.1 \pm 1.5$ after two years of $\mathrm{GH}$ treatment. Adult height $(-0.1 \pm 1.0$ SDS) was close to target height after $3.6 \pm 1.4$ years of GH treatment. Serum IGF-I levels increased significantly during treatment $(P<0.01)$. The treatment was well tolerated.

Conclusions: This proof-of-concept study shows that hGH treatment is associated with significant improvements in linear growth in adolescents with AN and severe growth failure. A randomized placebo-controlled trial is required to determine the ultimate impact of GH treatment in patients with this severe, rare condition.
\end{abstract}

Key Words

$\rightarrow$

$\rightarrow$

growth hormone treatment
Endocrine Connections (2017) 6, 839-846

\section{Introduction}

Anorexia nervosa (AN), a state of chronic nutritional deprivation, is a severe psychiatric disorder mostly affecting girls (1). It is associated with high morbidity and is accompanied by multiple neuroendocrine dysfunctions involving the growth hormone $(\mathrm{GH})$-insulin-like growth factor-I (IGF-I) axis, thyroid function, hypercortisolemia, http://www.endocrineconnections.org DOI: 10.1530/EC-17-0200
(C) 2017 The authors Published by Bioscientifica Ltd

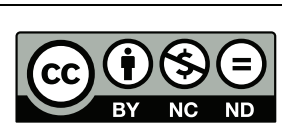

This work is licensed under a Creative Commons Attribution-NonCommercial-NoDerivatives 4.0 International License. 
hypogonadotropic hypogonadism and the levels of several adipokines and gut peptides, such as ghrelin and peptide YY (2). The pathophysiological mechanisms underlying pubertal delay or arrest and low height velocity (HV) are complex during the critical window for the pubertal growth spurt. These mechanisms may affect adult height, but they remain incompletely understood. After the patients' nutritional and mental states have been improved, catch-up growth is highly variable, from complete catch-up growth to a complete failure to gain height $(3,4,5,6,7)$. We previously showed that about one-third of girls with severe early-onset AN are at risk of adult height deficit (8). Patients may take several years to recover, and physical and mental disorders may persist in early adulthood in some cases $(8,9,10,11)$. There is, therefore, a limited time window for potentially effective treatment to improve HV in these patients.

Nutritionally acquired resistance to $\mathrm{GH}$, with high levels of this hormone and a disruption of the circadian dynamics of GH secretion $(12,13)$, high levels of the GH secretagogue ghrelin (14) and low serum IGF-I levels (15) have been reported in patients with AN. However, studies of $\mathrm{GH}$ secretion in children have yielded conflicting results, with low, high or normal GH levels detected $(16,17)$. The mechanism of $\mathrm{GH}$ resistance remains unclear and recent studies have suggested a role for the high levels of fibroblast growth factor (FGF)-21 produced by the liver and adipocytes in mediating $\mathrm{GH}$ resistance in patients with AN (18). IGF-I-IGF-binding protein (BP) adaptation in AN also appears to be different from that under other catabolic conditions, because the low levels of serum IGF-I are not associated with an increase in IGF-BP3 proteolysis, as reported for several other catabolic states (15). The changes in GH and IGF-I levels are at least partially reversed during refeeding and recovery (19).

The effects of supraphysiological levels of human $\mathrm{GH}$ on $\mathrm{HV}$ in these patients remain unclear. The administration of supraphysiological doses of hGH for four weeks is well tolerated in adolescents with AN (20), but a randomized placebo-controlled study of GH administration for 12 weeks in women with AN reported no increase in serum IGF-I levels (21). The catabolic effects of hGH on adipose tissue during the first few months of hGH administration are well known and may be of concern in children with AN. However, we showed in a previous study that hGH treatment has no long-term deleterious effects on adipose tissue mass or on body mass index (BMI) when administered to children of short stature who were born small for gestational age, with a low BMI at the start of treatment (22). We present here the first study on the effect of human-recombinant GH (hGH) therapy in 10 girls with $\mathrm{AN}$ and a very low HV over a prolonged period. The results were surprisingly favorable, as we obtained evidence of a significant increase in HV from the initiation of treatment in all these patients, resulting in adult heights close to target height.

\section{Patients and methods}

\section{Patients}

This retrospective observational study included the 10 adolescent girls followed for AN in the psychopathology department of our university hospital between 2002 and 2010, and treated with hGH for severe growth failure between 2004 and 2014. These girls were diagnosed with AN on the basis of the Diagnostic and Statistical Manual of Psychiatric Disorders, Fourth Edition criteria, at $10.0 \pm 1.9$ years of age. Their clinical characteristics before treatment are presented in Table 1. Consecutive patients were considered eligible for hGH treatment if they had a very low $\mathrm{HV}(<2.5 \mathrm{~cm} /$ year $)$ for at least 18 months despite improvements in nutritional status (at least a 10\% increase in weight) and clinical stabilization, with a pubertal Tanner stage $\leq 3$ and a bone age $\leq 13$ years. All patients had normal brain magnetic resonance imaging results and a normal karyotype. Patients were included regardless of their GH secretion status. The exclusion criteria were other known chronic diseases or the initiation of sexhormone treatment during the last year.

\section{Study protocol}

Clinical data for the patients were obtained from their medical records. We recorded clinical characteristics before the initiation of treatment, the initial dose and

Table 1 Pretherapy clinical characteristics of the 10 girls with anorexia nervosa.

\begin{tabular}{|c|c|}
\hline & Mean \pm s.D. or number \\
\hline Age at onset of AN (years) & $10.0 \pm 1.9$ \\
\hline Lowest BMI reached (SDS) & $-2.9 \pm 1.1$ \\
\hline Age at lowest BMI reached (years) & $11.5 \pm 1.1$ \\
\hline $\begin{array}{l}\text { Duration of hospitalization before } \\
\text { study entry (weeks)* }\end{array}$ & $30.4 \pm 20.0$ \\
\hline $\begin{array}{l}\text { Use of overnight nasogastric feeding } \\
\text { (weeks) }\end{array}$ & $4(40 \%)$ \\
\hline Associated comorbidity** & $n=9$ \\
\hline
\end{tabular}

*Never hospitalized $n=1$; **Depression $n=5$, anxiety $n=7$, obsessive compulsive disorder $n=3$.

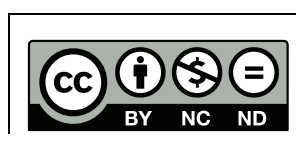

This work is licensed under a Creative Commons Attribution-NonCommercial-NoDerivatives 4.0 International License. 
management of hGH treatment during follow-up, total treatment duration, clinical and laboratory test results and outcome. Patients received a daily subcutaneous injection of open-label hGH at a mean initial dose of $0.040 \pm 0.006 \mathrm{mg} / \mathrm{kg} / \mathrm{day}$, based on the doses used in studies of patients with a short stature, because they were small for gestational age (23). As usual, the dose was adjusted according to weight and serum IGF-I levels. For safety reasons, if IGF-I levels reach an SDS of more than 2 for chronological age and pubertal stage according to our reference range (24), the dose should be decreased by $10 \%$. All but one of the patients treated for at least one year continued treatment for at least 2.4 years, until they reached near-adult height ( $\mathrm{HV} \leq 3 \mathrm{~cm} /$ year).

Patients underwent a physical examination at baseline and at each six-monthly visit. Height, weight and pubertal status were assessed. All patients were followed in both Endocrinology (every 6 months) and Psychiatry (every 1-6 months) Units. Other psychiatric comorbid conditions were recorded dichotomously as present or absent ('yes'/'no'). Inpatient treatment in the Pedopsychiatric Department was immediately proposed for subjects with a BMI less than $11 \mathrm{~kg} / \mathrm{m}$ (2) and/or cardiac, hemodynamic (bradycardia $\leq 50 \mathrm{bpm}$ ) or electrolytic complications.

Each patient was measured twice on a wall-mounted stadiometer, and the mean of the two measurements was recorded. Patients were measured by the same clinician (a pediatric endocrinologist) at each visit during the study to ensure consistency in the measurement technique used. Serum IGF-I, glucose and glycated hemoglobin concentrations were monitored during treatment, by determination at least once per year on non-fasting serum samples collected $12-20 \mathrm{~h}$ after hGH injection.

The study protocol was reviewed and approved by the institutional review board of Robert Debre Hospital, Paris 7 University, Assistance Publique Hôpitaux de Paris, which waived the need for written informed consent (reference number 2014/163). Patients and parents were informed that their data might be analyzed as part of a research study, and were considered to have given consent for such analysis if they did not object to this use of their data. Agreement for the use of data for research purposes was noted in the medical records of the patients, in accordance with the rules of our local ethics committee.

\section{Methods}

Height and BMI (weight/(height) ${ }^{2}$ in $\mathrm{kg} / \mathrm{m}^{2}$ ) are expressed as SDS for chronological age $(25,26)$. HV was determined from height records over the previous year and is expressed in $\mathrm{cm} /$ year. Pubertal development was assessed by determining Tanner stage. Target height SDS was calculated from mid-parental height (27). Bone age was determined blind, by the same investigator in each case, as described by Greulich and Pyle (28). Adult height was considered to have been reached if the patient had grown by less than $1 \mathrm{~cm}$ over the last six months and/or had a bone age $>15$ years.

Serum IGF-I concentrations were measured by immunoradiometry (IGF-I RIACT, Cisbio Bioassays, Gif sur Yvette, France). The inter-assay coefficient of variation was $<9 \%$ and the limit of detection was $9 \mathrm{ng} / \mathrm{mL}$.

Serum GH concentrations were measured with a two-site immunoradiometric assay (HGH-RIACT, Cisbio Bioassays, Codolet, France). The intra- and inter-assay coefficients of variation were $<2.5 \%$ and $<6 \%$, respectively. The limit of detection was $0.01 \mathrm{ng} / \mathrm{mL}$ (with calibration against the 2nd international standard WHO IS 98/574: $1 \mathrm{ng}=3 \mu \mathrm{IU})$.

\section{Statistical analysis}

Results are expressed as means \pm s.D. or medians (25-75th percentiles) unless otherwise specified. Nonparametricpaired Wilcoxon tests were used for statistical analysis. Bonferroni correction was applied to adjust the significance threshold for multiple comparisons. All tests were two-tailed, and values of $P<0.02$ were considered statistically significant. All statistical analyses were carried out with SAS software, version 9.12 (SAS Institute Inc., Cary, NC, USA).

\section{Results}

The baseline characteristics of the 10 patients receiving hGH treatment are presented in Table 2. Despite an increase in BMI before entering the study, from $-2.9 \pm 1.1$ SDS at its lowest to $-1.3 \pm 1.3$ SDS one year before study entry and $-0.9 \pm 0.6$ SDS at the time of GH treatment initiation (Fig. 1), HV remained low in all patients, at a median (25-75th percentiles) of $1.0(0.7-2.1) \mathrm{cm} /$ year at entry into the study, at a mean chronological age of $13.3 \pm 1.1$ years and a bone age of $10.9 \pm 1.7$ years. Puberty had already begun before the study in three patients (Tanner 2, $n=1$; Tanner 3, $n=2$ ). Serum IGF-I concentration SDS was low before treatment in all patients, and GH stimulation tests yielded values above the lower limit of the normal range (>20 IU/L) in only two patients. 
Table 2 Baseline characteristics of the 10 girls treated with hGH.

\begin{tabular}{|c|c|}
\hline & Mean \pm S.D. or number \\
\hline Age (years) & $13.3 \pm 1.1$ \\
\hline Bone age (years) & $10.9 \pm 1.7$ \\
\hline Height velocity (cm/year) & $1.3 \pm 0.9$ \\
\hline BMI (SDS) & $-0.9 \pm 0.6$ \\
\hline Height (SDS) & $-2.2 \pm 1.3$ \\
\hline Target height (SDS) & $0.4 \pm 1.3$ \\
\hline Height-target height (SDS) & $-2.7 \pm 1.4$ \\
\hline \multicolumn{2}{|l|}{ Pubertal stage } \\
\hline Tanner 1 & $n=7$ \\
\hline Tanner 2 or 3 & $n=3$ \\
\hline IGF-I (SDS) & $-1.8 \pm 0.7$ \\
\hline \multicolumn{2}{|l|}{ GH Peak } \\
\hline Above $20 \mathrm{IU} / \mathrm{L}$ & $n=2 *$ \\
\hline Below 20IU/L & $n=8 * *$ \\
\hline
\end{tabular}

${ }^{*} \mathrm{GH}$ peaks at 23.4 and $26.3 \mathrm{IU} / \mathrm{L}$, respectively; ${ }^{*} \mathrm{GH}$ peaks at 5.7 to $17.9 \mathrm{IU} / \mathrm{L}$ for the 8 patients.

\section{Growth during hGH treatment}

HV increased significantly during treatment, from a median of $1.0(0.7-2.1) \mathrm{cm} /$ year at baseline to 7.1 $(6.0-9.5) \mathrm{cm} /$ year after one year of treatment $(P<0.002)$ and $5.6(4.8-6.2) \mathrm{cm} /$ year after the second year of treatment (Fig. 2A and B). Height also increased significantly over the two years of treatment, from $-2.2 \pm 1.3$ to $-1.1 \pm 1.5$ SDS $(P<0.005)$. After a mean duration of hGH treatment of $3.6 \pm 1.4$ years, near-adult height was $-0.3 \pm 1.0$ SDS and, at the last evaluation, $1.2 \pm 0.7$ years after the end

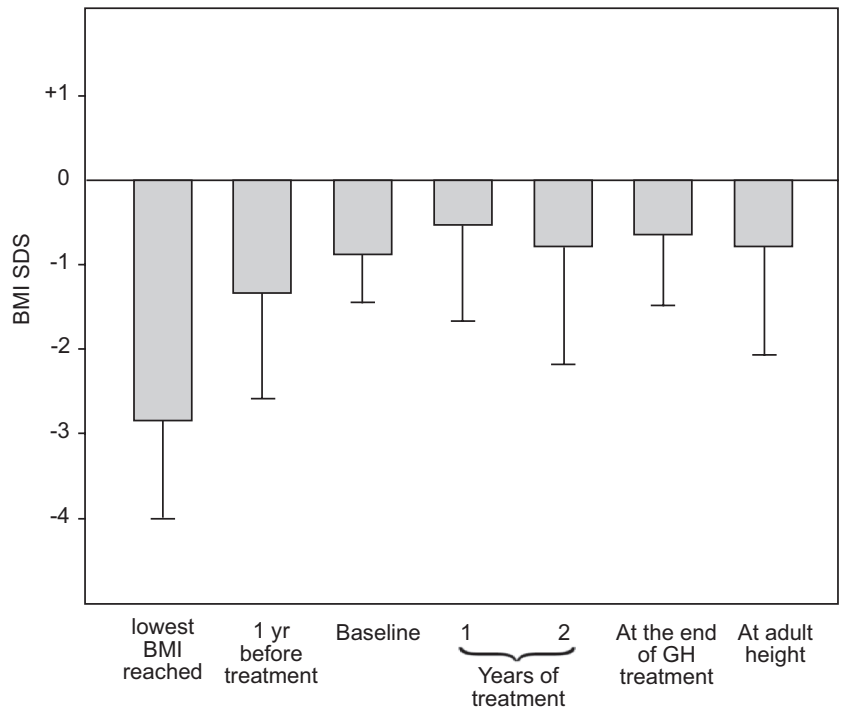

Figure 1

Changes in BMI SDS (mean \pm S.D.) over time in 10 girls with anorexia nervosa. of treatment, adult height was $-0.1 \pm 1.0$ SDS, close to target height.

\section{$\mathrm{BMI}$ and puberty during hGH treatment}

Mean BMI SDS remained relatively stable over the study period, but with some individual variability (Fig. 1 and Table 3).

Individual changes in pubertal stage among baseline, the end of hGH treatment and the last evaluation are shown in Table 3. Puberty was delayed in all patients. During the first two years of treatment, puberty advanced slowly in most of the girls, with one patient (patients 7) displaying no progression at all (remaining prepubertal). Puberty advanced by one stage in five patients (patients 1, 2, 5, 8 and 9), two stages in two patients (patients 4 and 10) and three stages in two patients (patients 3 and 6), over this time period (data not shown).

Following the cessation of treatment when $\mathrm{AH}$ had been reached, all but one of the patients was at a Tanner pubertal stage of 4 or 5 . The remaining patient was still at Tanner stage 3 (patient 1). Seven patients spontaneously reached menarche at a median (25-75th percentiles) age of 15.9 (14.5-17.0) years, a median of 2.6 (1.3-2.9) years after GH treatment initiation. Estroprogestative treatment was prescribed for three patients (patients 1, 7 and 10), one of whom (patient 1) refused this treatment.

\section{Serum IGF-I concentrations}

Serum IGF-I levels increased in all patients after hGH administration. Serum IGF-I levels increased significantly, from a median (25-75th percentiles) of 151 (126-277) ng/mL at baseline to 403 (349-591) ng/mL after one year of treatment $(P<0.01)$. Serum IGF-I levels were kept in the mid-normal range during the study and none of the patients had a serum IGF-I concentration SDS of more than 2 .

\section{Adverse effects during treatment}

Treatment with hGH was clinically well tolerated, and no side effects were reported. Two patients (patients 1 and 7) had to be admitted to hospital during the study period due to a relapse of AN, with weight loss and bradycardia. This led to a temporary interruption of hGH treatment, for 6 and 4 months in these patients, 1.0 and 2.5 years, respectively, after its initiation. http://www.endocrineconnections.org
DOI: 10.1530/EC-17-0200
() 2017 The authors Published by Bioscientifica Ltd
This work is licensed under a Creative Commons Attribution-NonCommercial-NoDerivatives 4.0 International License. 

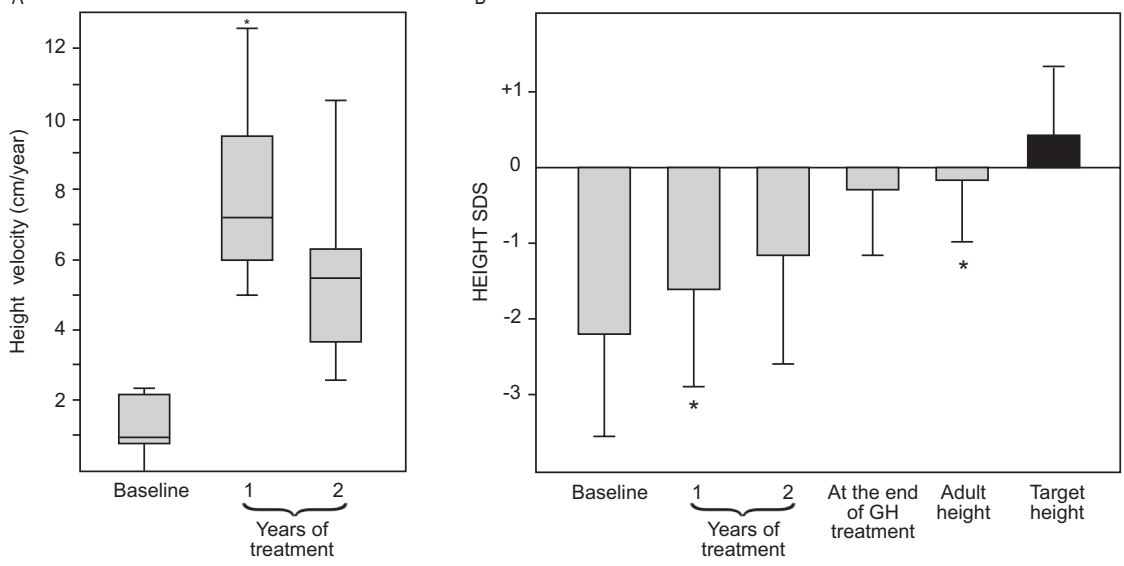

\section{Figure 2}

(A) Changes in height velocity in $\mathrm{cm} /$ year during the first two years of hGH treatment, in 10 girls with anorexia nervosa $\left({ }^{*} P<0.002\right.$ at the end of the first year, in paired non-parametric tests). Median, interquartile range and range are shown. (B) Changes in height SDS (mean \pm s.D.) during $\mathrm{hGH}$ treatment for $3.6 \pm 1.4$ years and until the attainment of adult height in 10 girls with anorexia nervosa $\left({ }^{*} P<0.002\right.$, at the end of the first year and at adult height, in paired non-parametric tests)

\section{Discussion}

This proof-of-concept study, the first to investigate the effects of hGH treatment in children with a very low $\mathrm{HV}$ due to $\mathrm{AN}$, indicates that hGH treatment can greatly increase HV in all patients within one year of treatment initiation. This increase in HV was also maintained in subsequent years, leading to a gradual increase in height and resulting in an adult height close to target height after a mean treatment duration of $3.6 \pm 1.4$ years in our patients. Another important finding was the increase in serum IGF-I levels in all treated patients. This is also the first time that such an increase has been demonstrated, as a previous study reported no improvement in serum IGF-I concentration following the administration of GH in young adult patients with AN (21). The mean GH dose used was $0.040 \mathrm{mg} / \mathrm{kg} / \mathrm{day}$ and serum IGF-I levels remained within the normal range throughout treatment in all patients. We cannot rule out the possibility that treatment with higher doses would result in an even greater effect, but our findings provide no direct evidence to support this hypothesis. Seven of the 10 patients were prepubertal at the initiation of hGH treatment. Pubertal stage progressed slowly in most patients and seven of the 10 patients underwent menarche spontaneously, a median of 2.6 (1.3-2.9) years after GH treatment initiation, demonstrating an improvement in their condition.

Despite a substantial increase in BMI before the start of GH treatment, mean BMI SDS did not normalize entirely. It remained relatively low in most patients and did not increase during the study period, suggesting that similar calorie intakes were maintained throughout the study, and that chronic mild eating disorders probably persisted in most patients, although this aspect was not closely monitored and considerable individual variability was observed. These data indicate that the increase in $\mathrm{HV}$ observed in these patients was probably related to $\mathrm{hGH}$ therapy, with only a minimal potential contribution of the improvement in nutritional intake and BMI before the start of hGH treatment. It has been shown that catch-up growth does not always begin during the first year of refeeding, when weight gain is rapid. Catch-up growth is more likely to occur during the second year of treatment and it may be difficult to discriminate between the accelerated growth rate of the pubertal spurt related to reversible functional hypogonadotropic hypogonadism and the catch-up growth related to the improvement in body weight (5). However, none of our patients displayed any catch-up growth during the two years after the improvement in nutritional intake preceding the initiation of hGH treatment. It remains unclear whether the higher rates of associated psychiatric comorbidities, such as depression and anxiety, in our patients (all but one patient affected) than would be expected for a pediatric AN population $(29,30)$ contributed to the persistent severe growth deficiency in our patients. A relationship among hypercortisolemia, anxiety and depressive symptoms and bone loss has been demonstrated in women with AN (31). Further investigations are now required to determine whether the hypothalamic-pituitary-adrenal axis hyperactivity delayed puberty with low levels of GH secretion, functional hypogonadotropic hypogonadism and mood disorders observed in our patients contributed to the poor growth observed. None of our patients had received estrogen replacement therapy before the study period. Physiological estrogen administration with transdermal estrogen replacement in adolescent girls with AN has been shown to improve the low bone mineral density related to this disorder significantly (32). However, further investigations are required to determine whether estrogen replacement during the pubertal period is also predictive of changes in $\mathrm{HV}$ in these patients.

This work is licensed under a Creative Commons Attribution-NonCommercial-NoDerivatives 4.0 International License. 


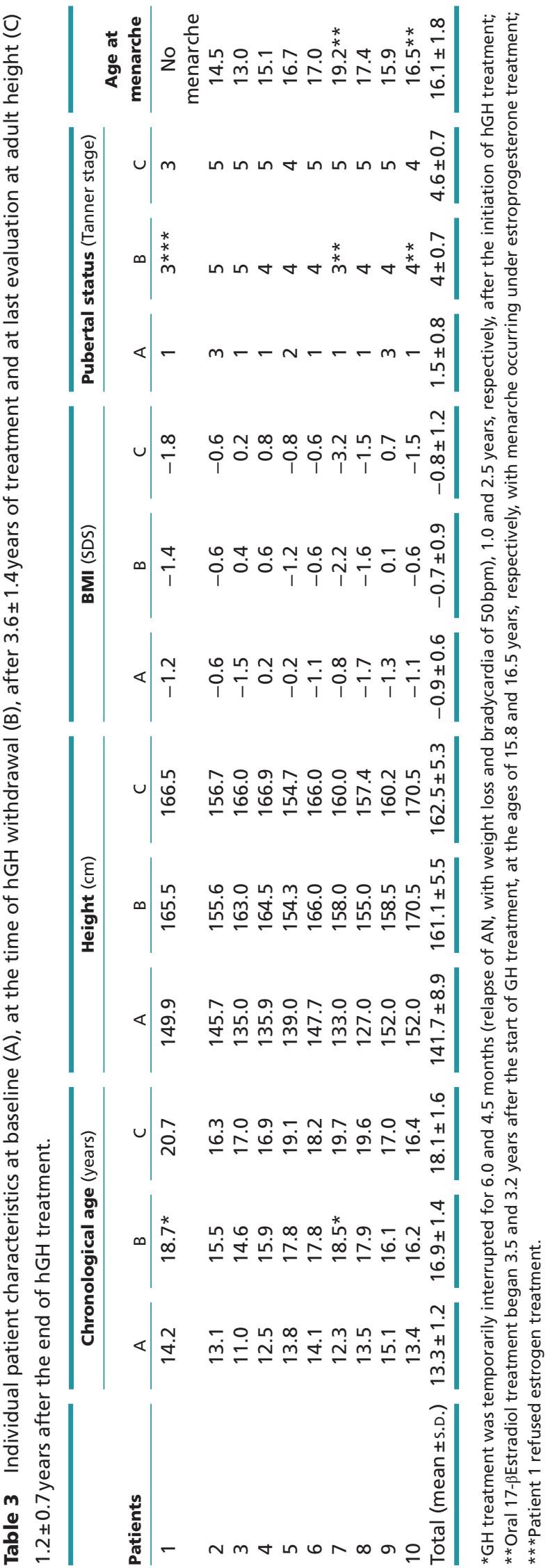

http://www.endocrineconnections.org DOI: 10.1530/EC-17-0200

2017 The authors Published by Bioscientifica Ltd
The results presented here should be interpreted in light of the limitations of the study. We performed a retrospective observational study with no control group of untreated patients. As such, we can provide no firm evidence that the outcome of our patients would not have been similar if they had not received hGH. We cannot exclude the possibility that they would have shown optimal growth. spontaneously. However, this is unlikely given that similar results for catch-up growth and an increase in serum IGF-I levels were observed following hGH treatment in all patients. Weight restoration remains the major clinical factor determining catch-up growth in children and adolescents with AN. However, despite weight gain and an increase in BMI, BMI values remained quite low in most of our patients with a very low HV for at least 18 months before the initiation of hGH treatment. However, the number of subjects investigated was small, because this complex condition with prolonged poor growth is very rare, and our study cannot, therefore, provide further insight into the mechanisms underlying the long period of very low $\mathrm{HV}$ and the catch-up growth observed following hGH treatment, although this treatment clearly increased serum IGF-I levels in all patients.

No adverse effects that could be directly attributed to hGH therapy were observed in this study. However, blood glucose levels and glycated hemoglobin concentrations are not sufficient to diagnose abnormal glucose metabolism, and basal insulin and glucose tolerance testing would be the only appropriate methods for addressing this question.

In conclusion, we report here the first evaluation of the efficacy of hGH therapy for increasing HV in a small cohort of children with AN and severe growth deficiency. Our results provide a rational basis for a large randomized placebo-controlled study to determine whether hGH therapy should be considered an appropriate option in the management of these patients, given the limited time window available for potentially effective treatment. The clinical relevance of such a trial, in terms of nutritional outcome, metabolism, bone mineral density, body shape perception and overall course of the disease, should also be investigated.

\section{Declaration of interest}

The authors declare that there is no conflict of interest that could be perceived as prejudicing the impartiality of the research reported.

\section{Funding}

This study was supported in part by the French Ministry of Health (Rare Disease Plan). 


\section{Acknowledgements}

The authors thank Didier Chevenne for the serum GH and IGF-I determinations.

\section{References}

1 Rosen DS. Identification and management of eating disorders in children and adolescents. Pediatrics 2010126 1240-1253. (doi:10.1542/peds.2010-2821)

2 Singhal V, Misra M \& Klibanski A. Endocrinology of anorexia nervosa in young people: recent insights. Current Opinion in Endocrinology, Diabetes and Obesity 201421 64-70. (doi:10.1097/ MED.0000000000000026)

3 Pfeiffer RJ, Lucas AR \& Ilstrup DM. Effect of anorexia nervosa on linear growth. Clinical Pediatrics 198625 7-12. (doi:10.1177/0009922 88602500101 )

4 Lantzouni E, Frank GR, Golden NH \& Shenker RI. Reversibility of growth stunting in early onset anorexia nervosa: a prospective study. Journal of Adolescent Health 200231 162-165. (doi:10.1016/S1054139X(02)00342-7)

5 Swenne I. Weight requirements for catch-up growth in girls with eating disorders and onset of weight loss before menarche. International Journal of Eating Disorders 200538 340-345. (doi:10.1002/eat.20182)

6 Modan-Moses D, Yaroslavsky A, Kochavi B, Toledano A, Segev S, Balawi F, Mitrany E \& Stein D. Linear growth and final height characteristics in adolescent females with anorexia nervosa. PLoS ONE 20127 e45504. (doi:10.1371/journal.pone.0045504)

7 Nehring I, Kewitz K, von Kries R \& Thyen U. Long-term effects of enteral feeding on growth and mental health in adolescents with anorexia nervosa--results of a retrospective German cohort study. European Journal of Clinical Nutrition 201468 171-177. (doi:10.1038/ ejcn.2013.244)

8 Roze C, Doyen C, Le Heuzey MF, Armoogum P, Mouren MC \& Leger J. Predictors of late menarche and adult height in children with anorexia nervosa. Clinical Endocrinology 200767 462-467. (doi:10.1111/j.1365-2265.2007.02912.x)

9 Johnson JG, Cohen P, Kasen S \& Brook JS. Eating disorders during adolescence and the risk for physical and mental disorders during early adulthood. Archives of General Psychiatry 200259 545-552. (doi:10.1001/archpsyc.59.6.545)

10 Wentz E, Gillberg IC, Anckarsater H, Gillberg C \& Rastam M. Adolescent-onset anorexia nervosa: 18-year outcome. British Journal of Psychiatry 2009194 168-174. (doi:10.1192/bjp.bp.107.048686)

11 Strober M, Freeman R \& Morrell W. The long-term course of severe anorexia nervosa in adolescents: survival analysis of recovery, relapse, and outcome predictors over $10-15$ years in a prospective study. International Journal of Eating Disorders 199722 339-360. (doi:10.1002/(SICI)1098-108X(199712)22:4<339::AIDEAT1>3.0.CO;2-N)

12 Stoving RK, Veldhuis JD, Flyvbjerg A, Vinten J, Hangaard J, Koldkjaer OG, Kristiansen J \& Hagen C. Jointly amplified basal and pulsatile growth hormone $(\mathrm{GH})$ secretion and increased process irregularity in women with anorexia nervosa: indirect evidence for disruption of feedback regulation within the GH-insulin-like growth factor I axis. Journal of Clinical Endocrinology and Metabolism $1999 \mathbf{8 4}$ 2056-2063. (doi:10.1210/jcem.84.6.5734)

13 Misra M, Miller KK, Bjornson J, Hackman A, Aggarwal A, Chung J, Ott M, Herzog DB, Johnson ML \& Klibanski A. Alterations in growth hormone secretory dynamics in adolescent girls with anorexia nervosa and effects on bone metabolism. Journal of Clinical Endocrinology and Metabolism 200388 5615-5623. (doi:10.1210/ jc.2003-030532)
14 Soriano-Guillen L, Barrios V, Campos-Barros A \& Argente J. Ghrelin levels in obesity and anorexia nervosa: effect of weight reduction or recuperation. Journal of Pediatrics 2004144 36-42. (doi:10.1016/j. jpeds.2003.10.036)

15 Stoving RK, Flyvbjerg A, Frystyk J, Fisker S, Hangaard J, HansenNord M \& Hagen C. Low serum levels of free and total insulinlike growth factor I (IGF-I) in patients with anorexia nervosa are not associated with increased IGF-binding protein-3 proteolysis. Journal of Clinical Endocrinology and Metabolism 199984 1346-1350. (doi:10.1210/jcem.84.4.5622)

16 Golden NH, Kreitzer P, Jacobson MS, Chasalow FI, Schebendach J, Freedman SM \& Shenker IR. Disturbances in growth hormone secretion and action in adolescents with anorexia nervosa. Journal of Pediatrics 1994125 655-660. (doi:10.1016/S0022-3476(94)70030-3)

17 Argente J, Caballo N, Barrios V, Munoz MT, Pozo J, Chowen JA, Morande G \& Hernandez M. Multiple endocrine abnormalities of the growth hormone and insulin-like growth factor axis in patients with anorexia nervosa: effect of short- and long-term weight recuperation. Journal of Clinical Endocrinology and Metabolism 199782 2084-2092. (doi:10.1210/jcem.82.7.4090)

18 Fazeli PK, Misra M, Goldstein M, Miller KK \& Klibanski A. Fibroblast growth factor-21 may mediate growth hormone resistance in anorexia nervosa. Journal of Clinical Endocrinology and Metabolism 201095 369-374. (doi:10.1210/jc.2009-1730)

19 Counts DR, Gwirtsman H, Carlsson LM, Lesem M \& Cutler GB Jr. The effect of anorexia nervosa and refeeding on growth hormonebinding protein, the insulin-like growth factors (IGFs), and the IGF-binding proteins. Journal of Clinical Endocrinology and Metabolism 199275 762-767. (doi:10.1210/jcem.75.3.1381372)

20 Hill K, Bucuvalas J, McClain C, Kryscio R, Martini RT, Alfaro MP \& Maloney M. Pilot study of growth hormone administration during the refeeding of malnourished anorexia nervosa patients. Journal of Child and Adolescent Psychopharmacology 200010 3-8. (doi:10.1089/ cap.2000.10.3)

21 Fazeli PK, Lawson EA, Prabhakaran R, Miller KK, Donoho DA, Clemmons DR, Herzog DB, Misra M \& Klibanski A. Effects of recombinant human growth hormone in anorexia nervosa: a randomized, placebo-controlled study. Journal of Clinical Endocrinology and Metabolism 201095 4889-4897. (doi:10.1210/ jc.2010-0493)

22 Leger J, Garel C, Fjellestad-Paulsen A, Hassan M \& Czernichow P. Human growth hormone treatment of short-stature children born small for gestational age: effect on muscle and adipose tissue mass during a 3-year treatment period and after 1 year's withdrawal. Journal of Clinical Endocrinology and Metabolism 199883 3512-3516. (doi:10.1210/jcem.83.10.5165)

23 Clayton PE, Cianfarani S, Czernichow P, Johannsson G, Rapaport R $\&$ Rogol A. Management of the child born small for gestational age through to adulthood: a consensus statement of the International Societies of Pediatric Endocrinology and the Growth Hormone Research Society. Journal of Clinical Endocrinology and Metabolism 2007 92 804-810. (doi:10.1210/jc.2006-2017)

24 Alberti C, Chevenne D, Mercat I, Josserand E, Armoogum-Boizeau P, Tichet J \& Leger J. Serum concentrations of insulin-like growth factor (IGF)-1 and IGF binding protein-3 (IGFBP-3), IGF-1/IGFBP-3 ratio, and markers of bone turnover: reference values for French children and adolescents and z-score comparability with other references. Clinical Chemistry 201157 1424-1435. (doi:10.1373/ clinchem.2011.169466)

25 Sempé M, Pédron G, Roy-Pernod MP. Auxologie, Méthodes et Séquences. Paris, France: Theraplix, 1970.

26 Rolland-Cachera MF, Cole TJ, Sempe M, Tichet J, Rossignol C \& Charraud A. Body mass index variations: centiles from birth to 87 years. European Journal of Clinical Nutrition 199145 13-21. http://www.endocrineconnections.org DOI: 10.1530/EC-17-0200 (c) 2017 The authors Published by Bioscientifica Ltd
This work is licensed under a Creative Commons Attribution-NonCommercial-NoDerivatives 4.0 International License. 
27 Hermanussen M \& Cole J. The calculation of target height reconsidered. Hormone Research 200359 180-183. (doi:10.1159/000069321)

28 Greulich WW, Pyle SI. Radiographic Atlas of Skeletal Development of the Hand and the Wrist. 2nd ed. Stanford, CA, USA: Stanford University Press, 1959

29 Nicholls DE, Lynn R \& Viner RM. Childhood eating disorders: British national surveillance study. British Journal of Psychiatry 2011198 295-301. (doi:10.1192/bjp.bp.110.081356)

30 Buhren K, Schwarte R, Fluck F, Timmesfeld N, Krei M, Egberts K, Pfeiffer E, Fleischhaker C, Wewetzer C \& Herpertz-Dahlmann B. Comorbid psychiatric disorders in female adolescents with first-onset anorexia nervosa. European Eating Disorders Review 201422 39-44. (doi:10.1002/erv.2254)

31 Lawson EA, Donoho D, Miller KK, Misra M, Meenaghan E, Lydecker J, Wexler T, Herzog DB \& Klibanski A. Hypercortisolemia is associated with severity of bone loss and depression in hypothalamic amenorrhea and anorexia nervosa. Journal of Clinical Endocrinology and Metabolism 200994 4710-4716. (doi:10.1210/jc.2009-1046)

32 Misra M, Katzman D, Miller KK, Mendes N, Snelgrove D, Russell M, Goldstein MA, Ebrahimi S, Clauss L, Weigel T, et al. Physiologic estrogen replacement increases bone density in adolescent girls with anorexia nervosa. Journal of Bone and Mineral Research 201126 2430-2438. (doi:10.1002/jbmr.447)

Received in final form 11 October 2017

Accepted 16 October 2017

Accepted preprint published online 16 October 2017 http://www.endocrineconnections.org DOI: 10.1530/EC-17-0200 (c) 2017 The authors Published by Bioscientifica Ltd 